\title{
Culinary traditions as key elements of cultural, educational and linguistic heritage transfer within the Israeli Hungarian community
}

\author{
VIOLA VADÁSZ* (1)
}

University of Pécs, Education and Society Doctoral School of Education, Ifjúság útja 6, H-7624 Pécs, Hungary

\section{RESEARCH PAPER}

Published online: December 03, 2020

(c) 2020 The Author(s)

\section{ABSTRACT}

This research was carried out in the framework of a larger qualitative study within the Hungarian community in Israel. The original aim was to identify and describe the appearance of the Hungarian language in the Israeli linguistic landscape. However, in the meantime, it became very clear that the existence and characteristics of the Hungarian community and the language they use is strongly connected to food and its position in the ancestral heritage. From that point, we aimed to show what it means to be Hungarian in Israel when it comes to cuisine and food as well as how culinary traditions relate to education and heritage transfer. Semi-structured interviews, biographical narrative interviews and participant observation as research methods shaped the complete picture we received. As the results show, few new initiations are slowly entering the canon of Hungarian-Israeli culinary traditions, but mostly it stands on its traditional feet. Wider communication, increased civic and youth awareness and reinforced gastronomic culture could promote new concepts and interest of younger people being interest in learning their culture and language of origin, and the related traditions.

\section{KEYWORDS}

linguistic landscape, heritage transfer, foodscape, education, community, gastronomic culture

\footnotetext{
"Corresponding author. 30 Tui Street, Oneroa, Waiheke Island, Auckland 1081, New Zealand. E-mail: viola. vadasz@gmail.com
} 


\section{INTRODUCTION}

Every culture has its basic elements which it was built upon. Language, symbols, norms, values, beliefs and cognitive elements are fundamental components that characterise people and groups. Attributes of cultures can be described using these elements but not in an utterly different way from other cultures. In countries that embrace more culture since the very early period of the country's existence, it is completely natural for communities to recognise and live-in each other's cultural system. Globalization and postmodern approaches made these interactions more common but did not create these opportunities by themselves.

According to Hall, in the modern world, those national cultures we were born into are the biggest sources of cultural identity (Appadurai, 1996). However, we define ourselves and we use it as an analogy. These identities are not 'imprinted' in our genes; we think about them as they are part of our nature. We imagine national cultures as communities. Hall refers to saying that on the other hand national culture is not something which was born with us, after growing up in a cultural system and we consider it as ours and embrace its values (Hall, 1997).

There are many other components of culture besides the basic elements which have great importance and created a common heritage for people of the same origin. Ron and Timothy declare that both tangible (e.g. buildings and artefacts) and intangible (e.g. music and ethics) are part of heritage (Ron \& Timothy, 2013), but the greatest emphasis is upon food, cuisine and culinary traditions as essential elements of a culture. Food and cuisine, besides their complementary function in a cultural environment, reflect cultural norms and values, realities and opportunities of a region in terms of diversity of ingredients and cultivation, as well as are bequeathed from generations to generations. Last but not least foodways and cuisine leave an imprint on other elements of human heritage such as religion, language, politics, agricultural landscapes and family relations (Timothy, 2011).

Language is not just a group of words; it is the entrance to a culture. A set of words and sentences would not be enough to create such strong element without having specific meanings and terminology common to similarly socialised people. We need language to communicate, to send a message and to evolve in its beauty. Language is transmitted from one generation to another, or, at least part of it is. While transmitting a language, loads of other information is passed on too. Starting from the basic elements we mentioned (values, norms) to perspectives, behaviours and whole histories of families, communities and countries. Conscious and unconscious beliefs, knowledge and traditions are transferred through generations. Thereby, languages we inherit, speak, learn, are surrounded by, effect and influence our complex thinking system (see Whorf, 1956), but we do not always need words to think, or to conjure up mental images, sensations, colours, feelings, etc. Our language(s) and thoughts are greatly influenced by our culture (traditions, habits, environment, human effects), and personates our ways of thinking, acting, talking, responding (see Birner, 2019). Studying a language also gives a taste and an insight into the culture it belongs to.

Languages people know, speak and hear come from a narrower and broader environment. A heritage language is what families bring with them when they move from one country to another or inherit within the family. At the same time, speakers of a heritage language are also expected to speak the language of the country or society they have moved to. In the context of the US and Canada, heritage languages are languages spoken by immigrants and their children (Montrul, 2012). The languages spoken by the host society are called majority languages with official 
status, while the heritage language is a minority language spoken by individuals or groups as a linguistic minority in the host society. Kharchenko extends the notion of heritage languages as well as to indigenous languages of a native population (Kharchenko, 2014).

Heritage speakers are early bilinguals. Some of them are simultaneous, others are sequential bilinguals. The common feature is that by the time these speakers grow up and reach adulthood, the heritage language becomes their weaker language (Montrul, 2012; Scontras, Fuchs, \& Polinsky, 2015). Why is that? Schlyter says that heritage languages are less used and if they do, then usually in restricted areas and contexts than the majority language of the host society. As well as a tendency of lagging in morphosyntactic and lexical development is perceptible in comparison to the speaker's stronger language, and grammar tends not to reach native-like development (Schlyter, 1993; Scontras et al., 2015). In many researches, the term 'heritage language' is often used as synonyms of 'native language', 'first language', 'L1' and 'mother tongue/language' (Kharchenko, 2014).

\section{BASIS OF THE RESEARCH}

This research was carried out in the framework of a larger research within the Hungarian community in Israel. The original aim was to identify and describe the appearance (and its forms) of the Hungarian language in the linguistic landscape of Israel. Possible ways of language maintenance (development and/or preservation) and the cohesion of the Hungarian community were also part of the interest. As the results were analysed, it became clearer that the existence and characteristics of the Hungarian community are connected in several ways to food and its position in ancestral heritage. To understand why food and cuisine is an inevitable factor in the cultural and linguistic heritage of people of Hungarian origin in Israel, it is important to see the history of the community behind.

\section{HUNGARIAN LANGUAGE AND COMMUNITY IN THE ISRAELI PERSPECTIVE}

The Hungarian language is part of the Ugro-Finnish language family. Since the 10th century, it has been living and constantly developing. The location and history of the country led to mainly lexical residues from German, Turkish and Slavic languages (Rosenhouse, 2012). It has a standard version and several geographical dialects. Like many other languages, Hungarian has remained to be a heritage language in Israel after the 'Hebrew only' and melting pot policies, estimated to be a language with under 100,000 speakers (Spolsky \& Shohamy, 1999) today. Other studies consider the number of Hungarian speakers rather small (about 65,000 speakers at present), and many of the speakers, especially the early immigrants already have passed away (Rosenhouse, 2012). In fact, the number of those with any degree of fluency in Hungarian is very difficult to measure with a degree of accuracy, and it is even more complicated to pinpoint the number of people with Hungarian origin or ethnicity. It is a language still heard on the street but has limited functions and decreasing intergeneration language and cultural transmission.

According to the Ethnologue database, Hungarian language in Israel reached the status of 'dispersed' but based on our results, unfortunately it already has exceeded this category. We positioned the Hungarian language in Israel in between level $6 \mathrm{~b}$ and 7 on Fishman's and Lewis- 
Simon's combined scale. Level $6 \mathrm{~b}$ on the scale has been labelled as 'threatened' languages and declared 'vulnerable' by the UNESCO. Level 7 has been labelled as 'shifting languages' and declared 'definitely endangered' by the UNESCO. Even though learning, speaking, using languages by ideological perspective is less typical today in Israel than it was in the past, and a more liberal attitude to foreign languages and cultures is perceptible.

\section{Hungarians in Israel}

'Native foods and their endemic ingredients, as well as the peasant or colonial origins of many popular foods today, contribute a great deal to the identity-making of nations and people' (Ron and Timothy, 2013: 3). In the 19th century there was one identifiable Hungarian Jewish community in Israel; even though they did not speak Hungarian, but identified themselves with Hungary. Aside from this small group of people, most Jews of Hungarian origin entered Israel in the 20th century, especially at the time of World War I and II. In 1948, a mass immigration to the newly established State had shaped a whole society, including the Hungarian community (Olosz, 2015, pp. 139-140).

It is a common habit to say that Hungarians are non-cohesive people. For some reason, it is very rare for Hungarians to form a cohesive community in diaspora and even within their own country. Looking at the Israeli example, in 1955, the Kastner-case caused several complications not only in the Israeli politics but has completely disrupted the unity of the Hungarian community (Olosz 2015, pp. 139-140). Either this disruption had a great impact, and the community never recovered from it, or fragmentation is just a general character of 'Hungarian-ness' abroad and inland. In the 1990s, Ben Rafael (1994) conducted a research on Hungarians in Israel and found the Hungarian language to have high ethnic significance but a weak transmission of 'Hungarian-ness' to the younger generation with signs of high language attrition. Our findings in 2019 show that, ethnically, Hungarians are still highly represented but it does not necessarily come with language proficiency. Transmission of 'Hungarian-ness' very much depends on which generation of immigrants we are talking about. Or can we even talk about more than one or one-and-a-half generations of immigrants? The first generation is clear, one-and-a-half are those who got to the host country as children or youth. Those, who we call second-generation immigrants were already born in the host country, thereby is their country of birth. They are not immigrants anymore, but their family carries the paradigm of immigration.

Generally, Hungarian just as other heritage languages are not fully protected against strong influences of other highly represented languages such as English or Hebrew: its future status and value are very much dependent on individual aspirations as well as on a not yet existing protective heritage language policy in Israel. Seeing weaknesses and contingencies of the cultural and linguistic heritage transmission in Israel within the Hungarian community, yet one phenomenon is very strongly represented: the respect for the ancestors and for the traditional cuisine. If something is highly respected within the community and well-known worldwide is the Hungarian cuisine, leastwise its special elements. Passion, insistence for food and what it represents in the family can unify diasporic groups and strengthen the feeling of national solidarity in many cases. That is what this article aims to present through the example of Israeli Hungarians whether they are Jews, Arabs, Christians, or belong to no religion. 


\section{HERITAGIZING GASTRONOMY}

Food is a foundational component of every culture. It is part of people's daily life but beyond that, is part of our long-term yesterdays. Habits, traditions are bound to it as it connects the present with the past. Transgenerational, sometimes inexplicable traditions, rituals are going through families, communities which people do not question, simple just follow the pattern they have learnt or were being taught. Origin, continuity, traditions and timelessness get great emphasis not only when it comes to national identity, but as well as when a family's identity gets represented (Hall, 1997). People treat it as something ancient, something continuous. Furthermore, even when individuals or communities move around the globe, and are constantly changed by their new contexts and by experiences, they still keep something which represents them. 'Diaspora cultures produce their difference with other populations in their dispersed contexts, a difference that is often expressed through an orientation toward origins and that always results in new hybrid subjectivities' (Wofford, 2016, p. 76).

An initiation called The Slow Food-CE project $^{1}$ formed a model for understanding and valuing the heritage of intangible knowledge related to gastronomic culture; their focus was on urban contexts. This model aims to identify and document gastronomic cultural resources.

Valuing the heritage of communities, cultures are not only important in the urban context, it is important in diaspora context via mobile communities which became the minorities living there. Transmitting rituals, methods of preparation, festal tradition often comes alongside with a transmitter language, even if it is not the primary language of communication within the family.

'Tales contain everything - all the things that exist, have ever existed or could have existed.'

Ildikó Boldizsár is one of the most famous therapists in Hungary who received her doctorate in folklore and was doing research on fairy-tales. She developed the Metamorphoses Therapy Method and published a book entitled Story Therapy. The topic of this book is not closely related to the subject of our research, but in certain ways, we see parallels between tales and food-related family stories. On the one hand, fairy tales are parts of the so-called archaic knowledge, a set of magical rituals with which one could constantly shape the world. It is a kind of 'thinking overthinking'. Knowing, hearing, transmitting tales connects each individual to a larger community, the community of humanity (Boldizsár, 2010). Transmitting, passing on family stories (including recipes, methods, habits, traditions, methods of preparation) alongside intangible heritage such as familiar flavours, taste, attraction to a culture, also connects each individual - even if she/he is a late descendent - to a larger community, the community of immigrants, of people of the same origin. It is a conscious and the same time, unconscious experience - in most cases, those stories heard, familiar flavours tasted in childhood find a way to make people interested in their own heritage.

'Food globalises while it localises, thereby crossing national boundaries' (Pollock, 2009, p. 103).

\footnotetext{
${ }^{1}$ Technical and methodological framework for development of the project SlowFood-CE: Culture, heritage, Identity and Food. O.T1.1 Model for the identification and documentation of gastronomic cultural resources - GCH mapping. Interreg.
} 
These days one nation countries are very rare, people move according to their own decision or because of danger or pressure. Pollock's paper about food and transnationalism shows that mobile communities have carried their gastronomies with them across space and time, just as well as individuals who had to or decided to leave their countries of origin. People have been transferring the cuisine, the traditions of their families, the feeling of hominess that meals from their childhood can bring up.

The foodscape of a country is made up of several elements. It takes a result of past and present influences, experiences and traditions of communities living there, diverse map of the world's cuisine as well as respect for food in the enhancement of cultural identity (Pollock, 2009). Israel is a melting pot of cultures both in terms of history, religion, linguistics and of course, gastronomically.

\section{HUNGARIAN FOODSCAPE IN ISRAEL}

Pollock describes those key features of modern gastronomy that contribute to the depiction of a foodscape:

- The origin, diversity and material form of food.

- The ideology behind usage, eating situations and the values on which food use is based.

- Events, festivals, feasts associated with specific food; the process of cooking, preparation, preservation.

- Social relations in which food are embedded.

- Myths and legends associated with particular foods and event (Pollock, 2008, 2009, p. 104).

This article aims to demonstrate what it means to be Hungarian in Israel when it comes to cuisine and food. Hungarian foodscape and the linguistic landscape are closely related fields in the Israeli case.

'Hungarian cuisine is an inseparable part of the culinary richness that makes up the diverse menu of Israeli society, with its various communities and flavours'.

That is how the description and invitation of The Year of Hungarian Culture ${ }^{2}$ explained the role of Hungarian cuisine in the Israeli gastronomy. This festival was the largest Hungarian event in Israel in 2019; it aimed to celebrate 31 years of renewed diplomatic relations between Israel and Hungary. Over 100 days, 20 productions and more than 1,000 guests arrived from Hungary to present the wide and colourful range of artistic activities and rich cultural life in Hungary to the Israeli public. As the preface of the festival brochure said, Hungarian culture is not foreign to Israelis. Moreover, it is an integral part of its diverse cultural life. The greatest emphasis among the events and productions was upon gastronomy and related fields. A culinary week took place in March 2019 in the biggest cities of Israel such as Haifa, Jerusalem and Tel Aviv. Chefs, confectioners, culinary experts arrived in selected restaurants and bakeries and served meals and pastries of Hungarian origin or influence. During October 2019 the port of Tel Aviv hosted a cultural gastronomic outdoor Hungarian festival called 'Happy Hungary Days of

${ }^{2}$ http://hungary-israel.co.il/en/about-us-2/. 
the Year' which this year is part of The Year of Hungarian Culture but has been going on for four years. The festival offered plenty of Hungarian food stalls in rich and varied offerings, wine tastings alongside cultural and folklore events. The difference between the culinary week and the Happy Hungary Days of the Year is the range and style of food. The first event focused on today's modern gastronomy, young chefs and innovations, to what today's generation imagines as directions of Hungarian cuisine. The second event at the port offered a very traditional gastronomic route more alike favours the ordinary flavours, known and famous dishes. Both attracted a variety of interested people from several aspects: age (generation), nationality, taste, etc.

Israel's Hungarian food and linguistic landscape offers a lot more than festivals in terms of restaurants, cooking supply shops and markets. Several shops and restaurants in Tel Aviv offer have a few types of traditional Hungarian dishes besides sweets and imported seasonings. In most cases, product information is available in Hebrew only, but the name of the actual product was kept in the original language by the distributor (Erös Pista - a strong paprika cream; Mustár - mustard, Torma - horseradish, etc.).

Sometimes a language appears in the most unexpected way in the culinary landscape. This box of a cake decorated in several languages saying true love. It was found in one of the top bakeries in Tel Aviv. In Fig. 3, the same text can be read in Hungarian: 'igaz szerelem'.

Kjortosh, קיורטר, kürtös (kalács) - a very well-known term by Israelis who have a sweet tooth. The name in Hebrew comes from a mispronunciation of ' kürtös' - in Hebrew people can rarely pronounce the vowels ' $\ddot{\mathrm{u}}$ ' or 'ö', instead of that they changed the sounds to 'o'. The Hebrew language tends to write foreign words phonetically, that happened to this Hungarian word as well. On the wrapping the name of the cake is written in Hebrew: קיורטוש - kjortosh, below the explanation: המאפה ההונגרי, the Hungarian pastry.

Recently, the same shop appeared on the famous Carmel Market (besides the original one on Bograshov street) where people stand in long lines in order to get 'kürtöskalács', chimney cake, kjortosh, kurtosh - however, people call it. It is a spit cake specific to Hungary and Hungarianspeaking regions in Romania, made with layers of dough or batter deposited, one at a time, onto a tapered cylindrical rotating spit. ${ }^{3}$ Earlier it was a festive treat, and now, it is possible to buy it every day just as well in Israel as in Hungary.

There as well are examples for misleading signs in the Linguistic landscape in a the sense of no real connection to the culture of origin or its people. Hungarian Blintzes is a restaurant in North-Tel Aviv with no other connection to Hungary and its language than its name, but their website promises real Hungarian food. According to informants, the restaurant is run by Georgian people who just kept the name of the place they have bought from someone else. The best-known dish they serve is called blintzes which many times are a reference to a Hungarian sweet dish called 'palacsinta'. It is a French crepe type dessert. The original Hungarian word for what they mean by blintzes is not mentioned anywhere on the menu.

In contrast to the other place, Tulip is a well-known Hungarian restaurant with authentic dishes, Hungarian owners and a respected chef. On an average day, $70 \%$ of the guests are office workers from the companies nearby, the other $30 \%$ of visitors are people of Hungarian origin (new guests and frequenter ones as well). The most interesting time to actually be in a

${ }^{3}$ https://en.wikipedia.org/wiki/Spit_cake. 


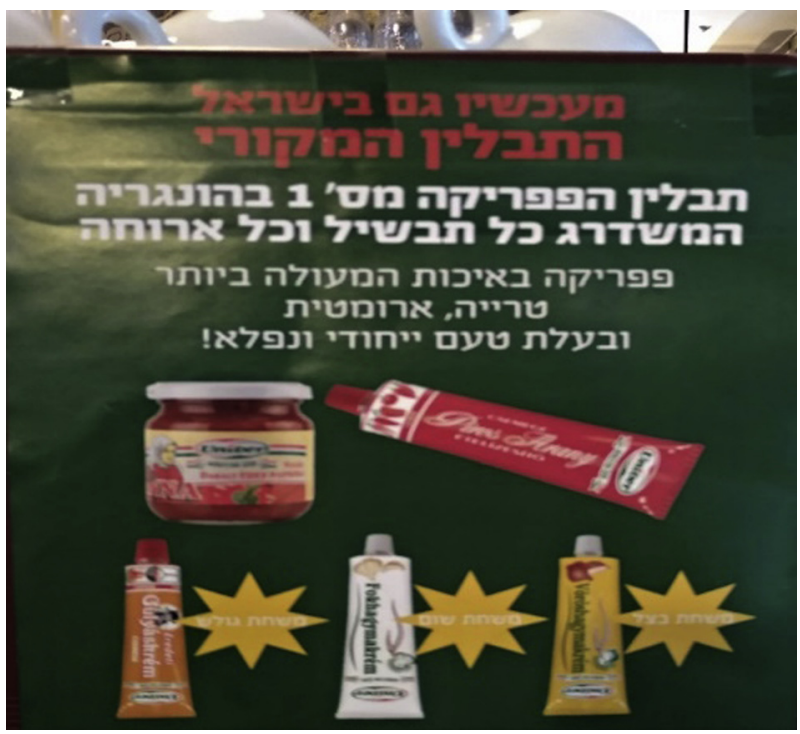

Fig. 1. Traditional Hungarian seasonings offered in an Israeli restaurant (Souce: Tulip restaurant, photographed by the author in 2019)

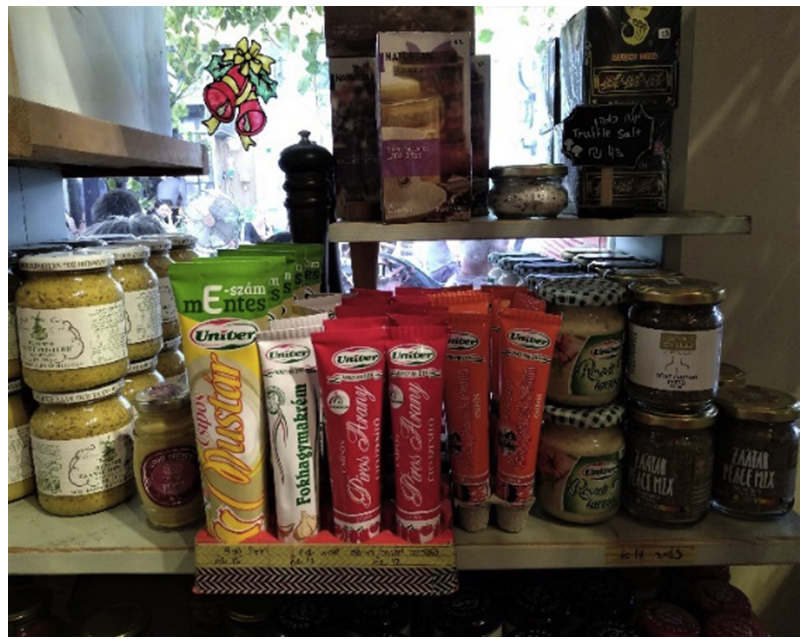

Fig. 2. Traditional Hungarian seasonings offered in an Israeli delicatessen in Jaffa (Photographed by the author in 2019) 


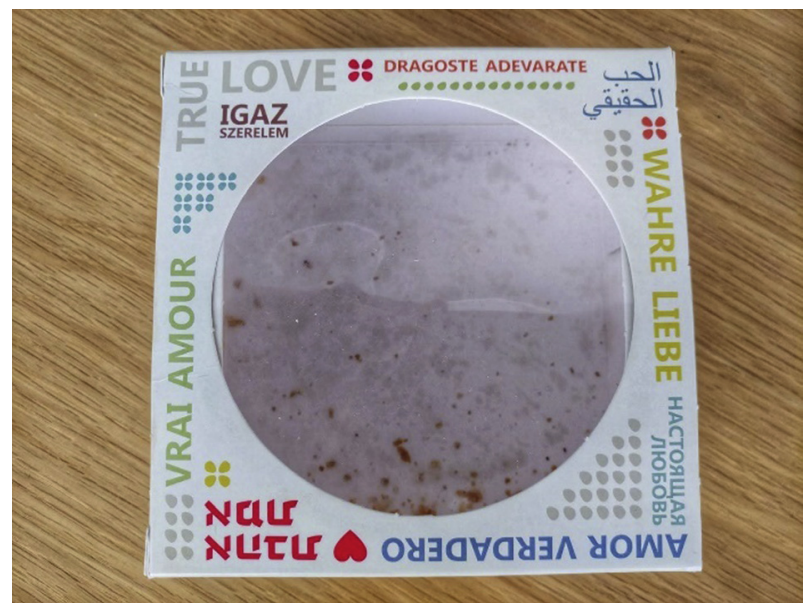

Fig. 3. A box of a cake from the bakery 'Lechamim' (Photographed by the author in 2019)

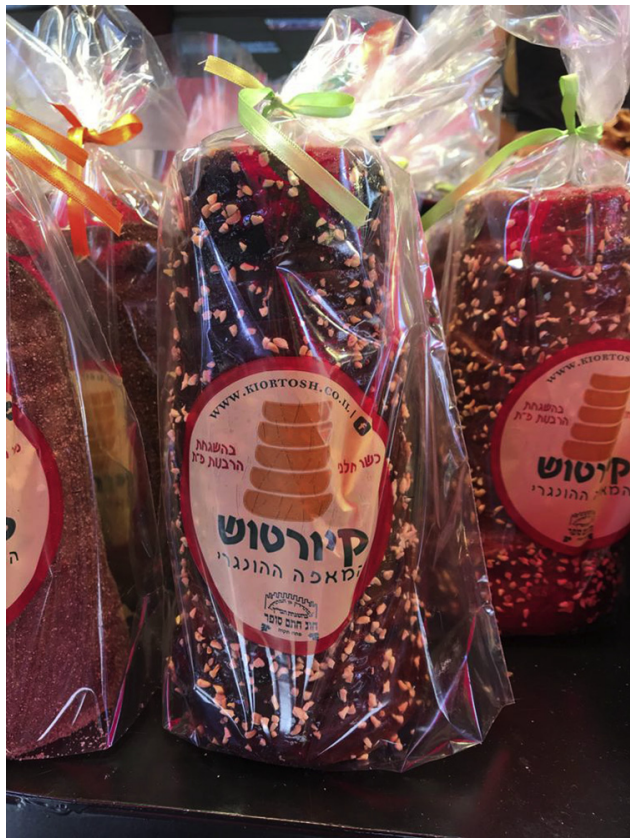

Fig. 4. A bunch of 'kürtös' at the Carmel market (Photographed by the author in 2019) 
Hungarian culinary land- and soundscape is Friday evening when families of Hungarian origin sit at almost every table. Most come from the grandparents' generation and feel like spending a Shabbat evening at a place which reminds them of their past. They come to the restaurant to hear Hungarian words, to eat the food they adore, and to remember their ancestors.

'Many times, the descendants are learning Hungarian words from us. Many young people, especially workers in high-tech, come here for lunch who once had a Hungarian grandmother or grandfather. They themselves don't speak the language but after I pronounce the name of the food on the menu with correct Hungarian accent, they try to say it as well. Many times, memories just come up, they cry, we had many very emotional moments.'

The couple who own the place feels that they are some kind of representatives of the Hungarian culture and language through gastronomy and hospitality. Even if they have to say the names of the food correctly a hundred times a day just to remind someone of her/his ancestors, they will do so because in this way they feel they are contributing to the preservation of the cultural heritage. They used to keep brochures, information booklets on Hungary at the restaurant, and give to their customers. Many of the guests have visited Hungary just because the owners strongly recommended it.

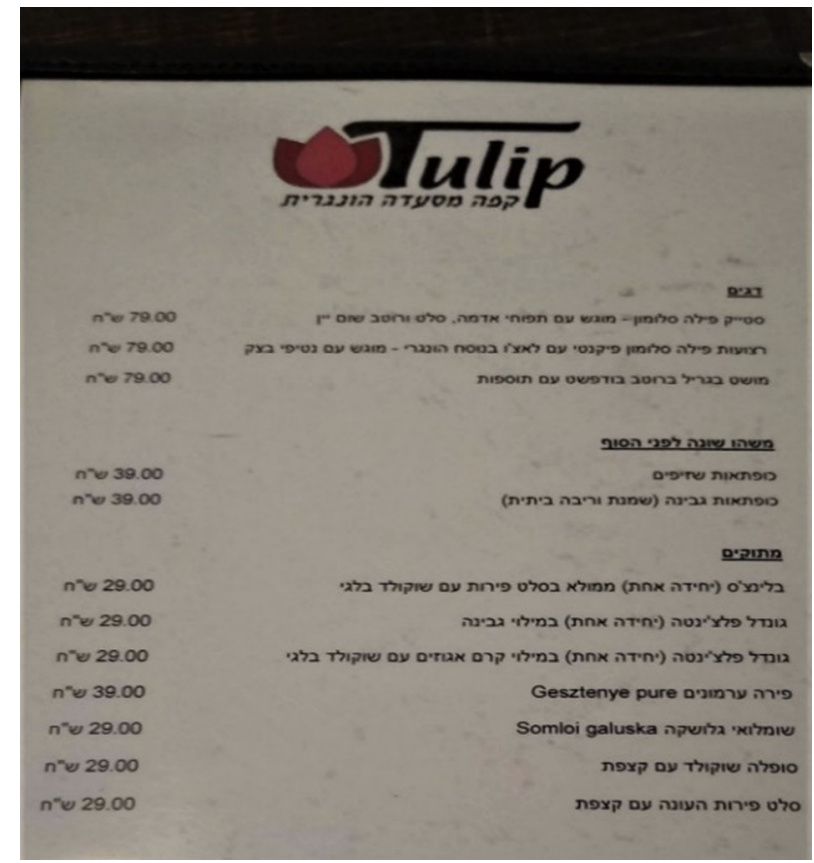

Fig. 5. The dessert menu of Tulip: Gesztenye pure (chestnut puree) and Somloi Galuska (sweet dumplings) written in Hungarian (Photographed by the author in 2019) 
Jerusalem offers kosher dairy Hungarian food in a chef restaurant called IgenMigen ${ }^{4}$ - a Hungarian restaurant with no meat, but loads of dairy food and their name written on the menu in Hungarian: langos (lángos - a deep-fried bread), kalács (braided brioche), rakott krumpli (a baked dish of layers of potatoes, sour cream etc.), Paprika (which probably refer to Paprikás, a stew) and töltött káposzta (stuffed cabbage).

The most famous Hungarian dish worldwide is goulash (gulyás in Hungarian), some people call it the national dish or the symbol of the country. It is either a stew or soup of meat and vegetables usually seasoned with paprika and other spices. The popularity of world-recognised food has launched an initiative which was called: Gulyásparti, i.e. goulash-party. The first Gulyásparti was in 2015, organised by a young Hungarian scholarship-holder who was sent to Israel under the Körösi Csoma Sándor programme (this program of the Hungarian government targets more remote countries, mostly the Hungarian diaspora, and assigns young Hungarians every year to help Hungarian communities preserve their identity and language). Since 2015 there were three very successful and large Gulyásparti-s and a smaller event in 2018 which was more like a cooking competition than the previous events where people were hosted. The idea behind these events was built around a dish, but this dish is kind of a legend and has a very specific symbol within the community. Hundreds of people participated from the youngest to the oldest generations. Even those came who are not particularly engaged to the community for different reasons (ideology, politics, history, attitude), but an event with only one ideological objective (to entertain and spend time together) served them all.

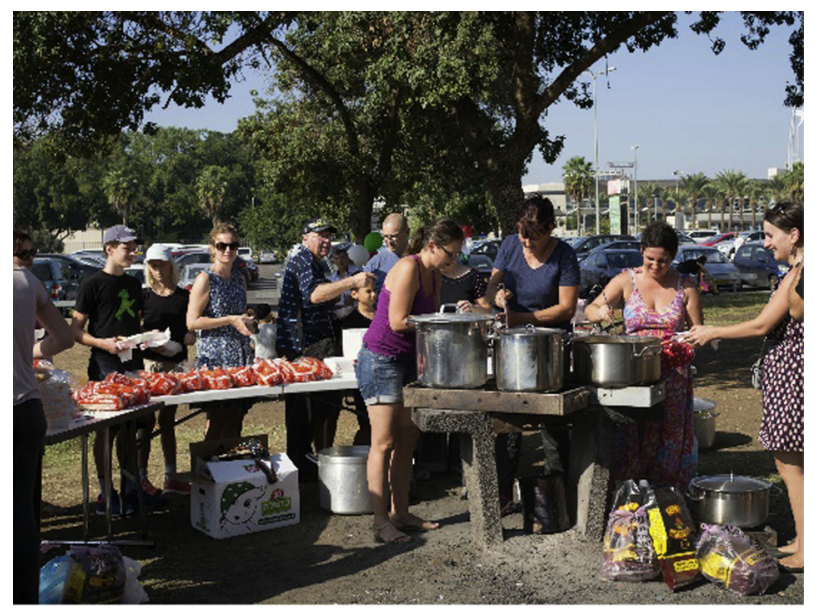

Fig. 6. Gulyásparti (goulash-party) (Photographed by KCSS scholarship-holder in 2015/16)

\footnotetext{
${ }^{4}$ In Hungarian, the word “igen' means yes. 'Igen migen, haf de fliegen,' is a slightly mocking expression used for Hungarian Jews, translating roughly to "Hungarian Jews, go jump in the lake.' (Source: IgenMigen Chef Restaurant Facebook Page).
} 


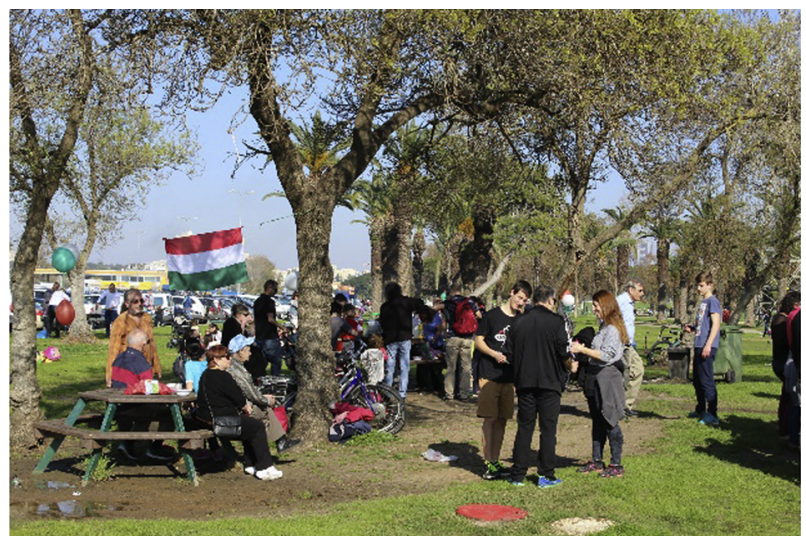

Fig. 7. Gulyásparti (goulash-party) (Photographed by KCSS scholarship-holder in 2015/16)

These gulyás (goulash)-related events were as well part of the yearly meetings of the Hungarian Kindergarten and School in Tel Aviv - they did not belong closely to the curriculum or teaching plan. However, they were a great opportunity for kids to be together on an ordinary weekend with people of Hungarian origin outside of their families.

Currently, there is no Hungarian as minority or heritage language education at any Israeli universities, and there is no cultural institute which would officially represent the language. Despite no official representation or support every so often some bottom-up action emerges from scratch, and become stronger as a result of a community initiative. From an initiation established 12 years ago, a foundation has grown, and with the support of the Embassy of Hungary in Israel, a weekend school and kindergarten operate within the framework of the Efraim Kishon Hungarian Education Centre. Kids of Hungarian origin come together every second Friday and study mostly in two study groups (depending on their age) how to read, write and speak Hungarian. Play and cultural activities get a big role during the 'school-year'. Every Hungarian holiday (national and religious as well) are celebrated where the presence and participation of parents and grandparents play a big role.

These cultural activities and celebrations often include food or food-related parts; many times, families take part in competitions (drawing, cooking), and through these events, kids get a picture on what certain dishes represent or mean to the community, and a special knowledge is passed on to generation by generation.

After seeing how the Hungarian community itself raises awareness of its culinary tradition, let us take a look at what Israelis think about Hungarians in general and the food they brought into the country. The preface of the book \#Izrael70magyar was written by Jair Lapid, a representative of Hungarian origin of the Israeli Parliament (Knesset). His father, Yosef (Tommy) Lapid was a famous journalist, tv and radio presenter of Hungarian origin as well. According to his famous saying:

'Jewish people came to life in the country of Israel - then Hungarians came and said: Come on, sit down and let's eat something!' 


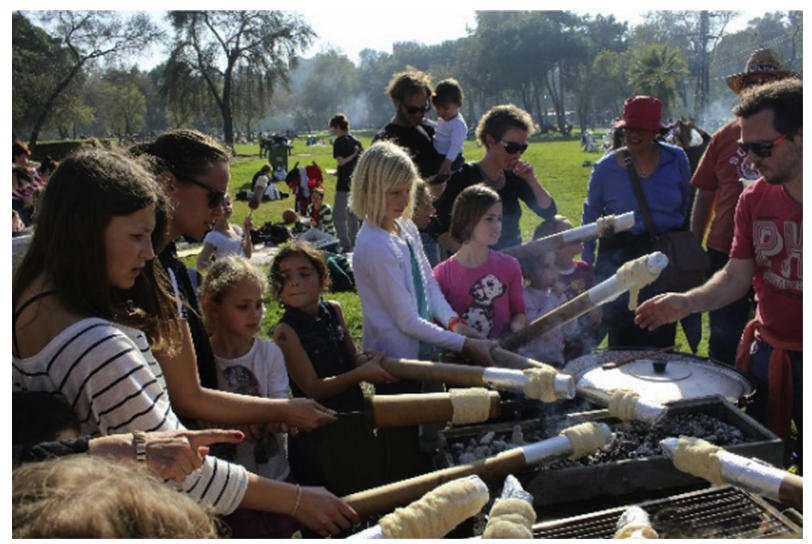

Fig. 8. Gulyásparti (goulash-party) - students and their parents (Photographed by KCSS scholarship-holder in $2015 / 16$ )

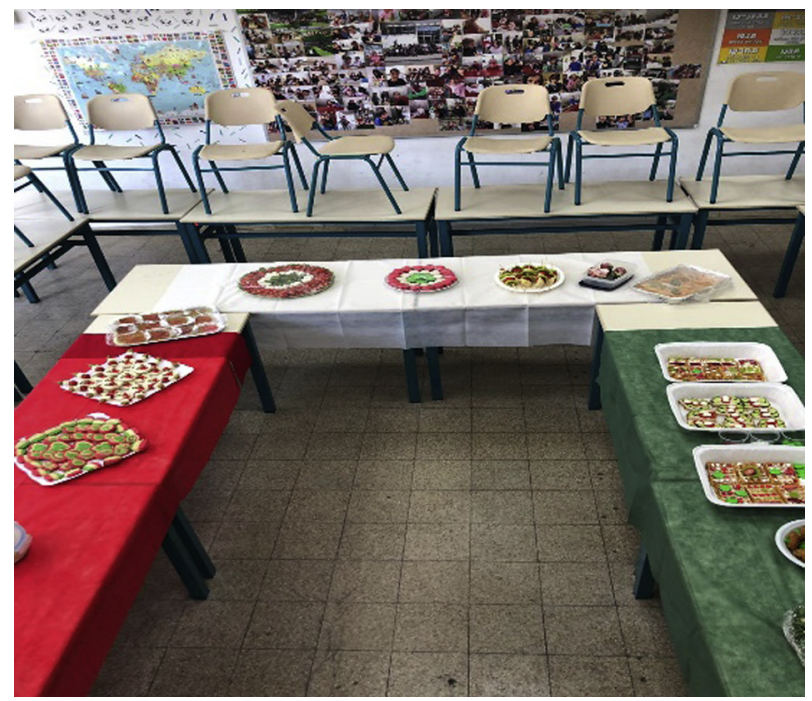

Fig. 9. Food competition on the topic of the colours of the Hungarian flag (Photographed by the author in 2019)

'Man eats - written by my father in the foreword of his Hungarian cookbook called Paprika - to live. Hungarian man lives to eat.'

'The most prominent feature of Hungarian Jewishness was the love of life and humour. They loved to eat, they liked to drink, they liked to laugh (we all, except Kishon, who was usually bitter), loved to 
love. Hungarian women had peach-coloured skin, and their eyes were naughty. Men quarrelled in the living room, pleading that they would never talk to each other again, and then they talked about it for an hour while kids escaped into the kitchen and burned the rest of the cabbage casserole (rakott káposzta) which was made exclusively for the guests.'

Hungarian food is heavy, paprika-oriented, but comforting. Whoever is asked in Israel about 'Hungarians' is able to mention at least one or two types of food with a great smile on his face. According to informants, even those people of Hungarian origin who never have learnt the language connects to the culture through the gastronomy.

'Szilvásgombóc (plum dumplings), that's all they know' (Informant 4)

As mentioned above, many people in the past decades were not allowed to learn or use any heritage or family languages publicly, Hebrew only policy was applied. Nevertheless, no political power had enough strength to prohibit cooking or baking by the culture of origin, and for many people, that is all was left from their past. Food names, expressions, recipes in original language have remained and preserved. For descendants and younger generations, this remaining knowledge could also be a heritage or bonding as well as the beginning of an arousing interest of their heritage and family history.

Photographs of old books and recipes in Israeli homes show a wide range of diversity in linguistic and cultural aspects as well. Israelis keep cooking books and notebook of recipes of their mothers and grandmothers as a treasure; items which are most dear to them. In many cases (especially refers to descendants of the Holocaust survival generation or people coming in the first waves) people of Hungarian origin are able to read the title of a recipe or the book, but the method not anymore. That they probably know by heart.

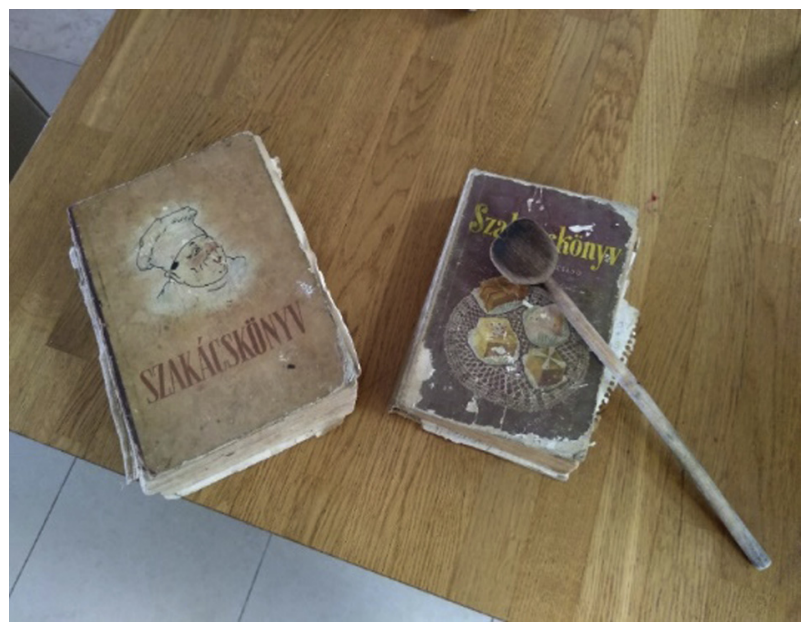

Fig. 10. Old Hungarian cookbooks in an Israeli-Hungarian home in Jaffa (Source: Informant 9, photographed by the author in 2019) 


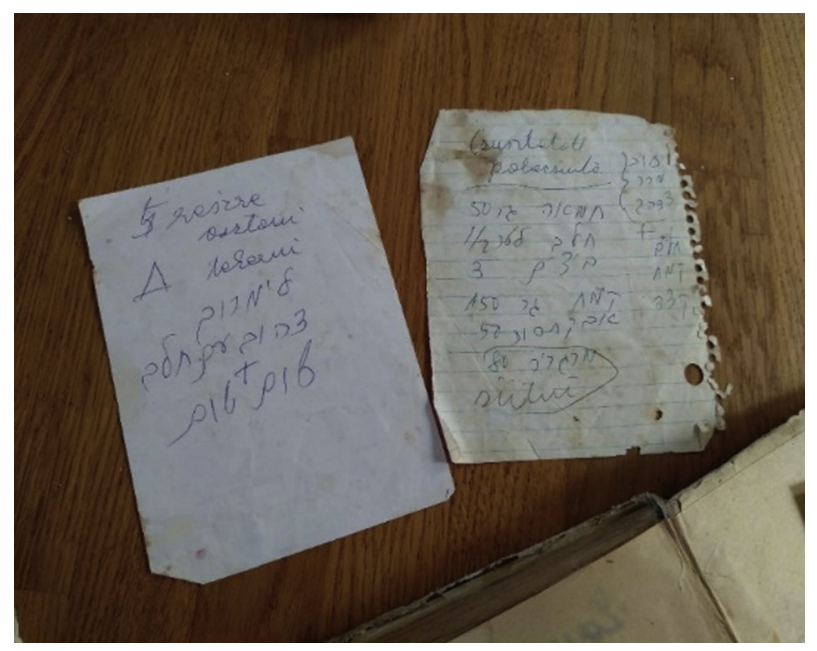

Fig. 11. Old recipes with Hungarian titles (names) and Hebrew explanations (Source: Informant 9, photographed by the author in 2019)

Ofer Vardi, an Israeli journalist of Hungarian origin grew up eating Hungarian-type of food made by his grandmother. When she passed away, he realised that those familiar and friendly flavours and aromas were gone as well with her. He started to share her recipes in a weekly column on one Israeli news site, and his articles attracted thousands of followers. He began to transform his knowledge and the well-known recipes into a book which was dedicated to anyone who longs for Hungarian Jewish cuisine. Going Paprikash includes a recipe box with more than 100 easy recipes for the purpose of recreating the much-loved flavours of a time gone by. ${ }^{5}$

Seemingly, Paprikash (is a name of a Hungarian dish resembling goulash - a paprika-based potato or bean stew - but without potatoes and using meat instead, mostly chicken) is a very popular and well-known dish within the Israeli Hungarian community regardless of age, gender or religion. An online group called 'HaPaprikashim' has lots of followers on the biggest social network page. People of Hungarian origin share their memories mostly on two topics: food (cooking, recipes, longing for a specific flavour, ways of cooking, etc.) and visits in Hungary (experiences, bad and good feelings). This online community is just as part of the Israeli Hungarian Linguistic Landscape as other initiations even though most members have a limited level of language proficiency.

'Sometimes they write Hungarian words with Hebrew letters, then someone from the elders corrects it. Those who are not familiar with the Hungarian alphabet are trying to use the English one.' (Informant) 
Why do food and some special dishes such as goulash and paprikash play a significant role in heritage language and culture maintenance? Because, especially in the Israeli case, it's the only topic which does not carry a pejorative sense, and does not bring up any complicated emotional story. Especially, in case of Holocaust-survivors for whom Hungary at the same time means their happy childhood with family memories, but as well persecution and loss of their family. For newer generations the country itself means lots of different things, positive and negative too, depending on each individuals' own story, but part of its culture can have a common meaning. We see this common meaning appear in the form of gastronomy and cuisine, which are less likely loaded or not even loaded at all with negative connotations even in diasporas with a complicated history. Other elements of culture, such as literature, language, history, religion, traditions, economy or national symbols could more be it. Probably, that is why flavours and aromas, and the memories they bring back are more likely to represent a pleasant feeling and connotation than any other culture-related memories. Cuisine and gastronomy allow individuals and families to remember their past and ancestors with positive affiliation and gather happily without having to feel attached to anything political or national. We believe that food is able to connect or patch people and communities peacefully, no matter who they are or identify with.

\section{CONCLUSIONS}

In particular, the topic of cultural heritage preservation and transmission, linked to gastronomic heritage and knowledge, is a fundamental step in the construction of a community's identity, especially if living in a diaspora. Innovative steps and development are many times results of slow processes, because most Hungarian communities living outside of the homeland, build their foundation on a strong common knowledge, on the well-known basics. That is why gastronomic events and culture are often archives of gastronomic memories of the past just as well as gatherings with positive affiliation and connotations. While the enthusiasm of current generations continues to exist and keep going, traditions will remain alive. The success of the next generations will depend on transgenerational transmission.

As results show, few new initiations are slowly entering the canon of Hungarian-Israeli culinary traditions, but mostly it stands on its traditional feet. Wider communication, increased civic and youth awareness, and reinforced gastronomic culture and knowledge could promote new concepts and interest of younger people. We believe that appropriate heritagization of material and immaterial cultural resources could increase the strength and position of the Hungarian community in Israel. Until then, cuisine represents the most peaceful way to make this connection.

Ethics: The study procedures were carried out in accordance with the Declaration of Helsinki. The Institutional Review Board of the Education and Society Doctoral School of Education (University of Pécs) approved the study.

Funding sources: This study was supported by the Campus Mundi international internship programme. 
Authors' contribution: Viola Vadász as author takes responsibility for the integrity of the data and the accuracy of the date analysis. V.V.: study concept and design, analysis and interpretation of data.

Conflict of interest: The authors declare no conflict of interest.

\section{ACKNOWLEDGEMENTS}

No additional acknowledgements.

\section{ABOUT THE AUTHOR}

Viola Vadász is a $\mathrm{PhD}$ candidate in the Doctoral Program on Sociology of Education at the University of Pécs. Her research focuses on supplementary education, teaching Hungarian as language of origin, education of immigrant children. In addition, the mapping of the Linguistic Landscape of the Hungarian language in Israel and in New Zealand is also part of her research interest.

\section{REFERENCES}

Appadurai, A. (1996). Modern at large. Cultural dimensions of globalization. Minneapolis: University of Minnesota Press.

Ben-Rafael, E. (1994). Language, identity, and social division: The case of Israel. (Oxford studies in language contact.) Oxford: Clarendon.

Birner, B. (2019). Does the language I speak influence the way I think?. Washington DC: Linguistic Society of America. https://files.eric.ed.gov/fulltext/ED426605.pdf [09 October 2019].

Boldizsár, I. (2010). Meseterápia (Story Therapy). Budapest: Magvető.

Hall, S. (1997). A kulturális identitásról. In Multikulturalizmus, szerk (pp. 60-85). Budapest: Feischmidt Margit.

Kharchenko, N. (2014). Heritage language maintenance or loss: A difficult choice for immigrant parents. https://umanitoba.ca/faculties/education/media/2014-Kharchenko-Nataliya.pdf.

Montrul, S. (2012). Is the heritage language like a second language?. EUROSLA Yearbook, 12, 1, 1-29. https://doi.org/10.1075/eurosla.12.03mon [10 October 2019].

Olosz, L. (2015). A magyar ajkú zsidóság helye az izraeli társadalomban. In: Fedinec Csilla (szerk.): Határhelyzetek VIII. Terek, intézmények, átmenetek (pp. 138-159). Balassi Intézet Márton Áron Szakkollégium Budapest.

Pollock, N. (2008). Chinese dietary influences in the Pacific. In J. Chou (Ed.). Proceedings of the 10th symposium of Chinese dietary culture. Taiwan: Foundation of Chinese Dietary Culture.

Pollock, N. (2009). Food and transnationalism: Reassertions of Pacific identity. In: H. Lee, S. Tupai Frncis (Eds.) Migration and transnationalism: Pacific perspectives (pp. 103-114). 
Ron, A. S. \& Timothy, D. J. (2013). The land of milk and honey: Biblical foods, heritage and Holy Land tourism, Journal of Heritage Tourism, 8, 2-3, 234-247. https://www.tandfonline.com/toc/rjht20/8/2-3 : Heritage Cuisines. http://dx.doi.org/10.1080/1743873X.2013.767817 [Accessed 07 October 2019].

Rosenhouse, J. (2012). Israeli Hebrew and Hungarian Interaction: phonetic/phonological issues. Text, Speech and Language Technology, 14/15. Rhythm, Melody and Harmony in Speech. Studies in Honour of Wiktor Jassem. http://www.ptfon.pl/files/2012_04-05.pdf [Accessed 09 October 2019].

Schlyter, N. (1993). The weaker language in bilingual Swedish-French children. In: K. Hyltenstam, A. Viberg (Eds.) Progression and regression in language. Sociocultural, neuropsychological and linguistic perspectives (pp. 289-308). Cambridge: Cambridge University Press.

Scontras, G., Fuchs, Z., \& Polinsky, M. (2015).Heritage language and linguistic theory. Frontiers in Psychology, 6, 1545. https://doi.org/10.3389/fpsyg.2015.01545 [09 October 2019].

Spolsky, B., \& Shohamy, E. (1999). The languages of Israel: Policy, ideology and practice (p. 312). Clevedon, UK: Multilingual Matters. Technical and methodological framework for development of the project Slow-Food-CE: Culture, heritage, Identity and Food. O.T1.1 Model for the identification and documentation of gastronomic cultural resources - GCH mapping. Inter Regions. University of Gastronomic Sciences 2018. https://www.interreg-central.eu/Content.Node/Model-for-gastronomic-culturalheritage-mapping.pdf. [07 October 2019].

Timothy, D. J. \& Ron, A. S. (2013). Heritage cuisines, regional identity and sustainable tourism. In C. M. Hall \& S. Gösling (Eds.), Sustainable culinary systems: Local foods, innovation, and tourism \& hospitality (pp. 275-290). London: Routledge.

Whorf, B. (1956): Language, thought and reality. Cambridge, MA: MIT Press.

Wofford, T. (2016). Whose diaspora? Art Journal, 75, 1, 74-79.

Open Access. This is an open-access article distributed under the terms of the Creative Commons Attribution 4.0 International License (https://creativecommons.org/licenses/by/4.0/), which permits unrestricted use, distribution, and reproduction in any medium, provided the original author and source are credited, a link to the CC License is provided, and changes - if any - are indicated. (SID_1) 